\title{
GROUP WINNING BLASTING AS A MEASURE TO MITIGATE SEISMIC HAZARD IN A DEEP COPPER ORE MINE, SW POLAND
}

\author{
Anna Barbara GOGOLEWSKA ${ }^{1 *}$ \\ Małgorzata KOWALCZYK ${ }^{2}$ \\ ${ }^{1}$ Wrocław University of Science and Technology, Department of Mining and Geodesy \\ ${ }^{2}$ Wrocław University of Science and Technology, Department of Mining and Geodesy, 2 Graduate from Wrocław \\ University of Science and Technology, graduate from Wrocław University of Science and Technology
}

\begin{abstract}
Three deep mines have been excavating the copper ore deposit in south-west Poland for about fifty years. Rock mass tremors and their effects such as rock bursts pose the most dangerous hazard which increases with intensity and depth of exploitation. The permanent growth of seismicity of the deposit necessitated the implementation of preventive activities into mining technology. Temporary and long-term as well as active and passive methods were developed to reduce or eliminate the hazard among which group winning blasting seems to be one of the most successful preventive technique. The paper aimed to assess seismic activity and the effectiveness of active prevention as well as to verify the connection between induced seismicity of rock mass and elements of blasting works. To realize the goal, seismic activity, the number of blasted faces, the number of explosives, and blasting-induced seismicity were analyzed. Moreover, the linear correlation coefficients between the aforementioned parameters and characteristics were calculated. One mining division of the Polkowice-Sieroszowice copper ore mine was investigated over three years during a high rate of seismic hazard and intense exploitation.
\end{abstract}

Keywords: copper ore deposit, underground mining, rockburst, induced seismicity, prevention measures

\section{INTRODUCTION}

The KGHM Polish Copper JSC which is situated in Legnica-Głogów Copper District (LGCD) in the south-western part of Poland has been producing copper and silver

\footnotetext{
* Corresponding author: anna.gogolewska@pwr.edu.pl (A. Gogolewska)
}

doi: $10.37190 / \mathrm{msc} 202711$ 
since the 1960s. Nowadays, it exploits deposits in Poland, Canada, the USA, Greenland and Chile. In Poland, excavation is carried out in three deep mines, i.e., Lubin, Rudna and Polkowice-Sieroszowice. The proved reserves of copper are the eighth in the world and those of silver, the third. Over 30 million $\mathrm{Mg}$ of copper ores containing about $2 \%$ of pure metal and significant amounts of silver are extracted annually. The average copper content achieves about $1.8 \%$ and silver amount reaches around $51 \mathrm{~g} / \mathrm{Mg}$ (Kijewski 2006). From the very beginning the three deep copper ore mines of KGHM PM JSC struggle with the rock burst and seismic hazards. Seismic activity has always been high and therefore threatened people and equipment with rock bursts. Consequently, the rockburst prevention has had to be implemented as an inseparable and unavoidable element of the mining technology and includes the recognition, monitoring and elimination of rock bursts. Measures used to assess the state of the rock mass in the G-23 division were based on observations of the roof, floor, acoustic effects, supporting construction and its behaviour. Detailed information on the rockburst hazard was obtained by measuring the convergence of excavations, measurements of seismic acoustic activity, permanent recording of seismic activity and seismic tomography analysis. The rockburst hazard was mitigated with the use of various preventive measures, which include technological, active and organizational technical ones. The active methods embraced group winning blasting of the maximum number of faces, winningrelieving blasting in the solid, also with maximizing the number of faces, blasting in the floor and the roof when necessary (Kijewski 2006; Konopko 2009; Butra 2010).

So far, the group winning blasting has been the most crucial active method to decrease rockburst hazard, therefore the paper aims to assess this method efficiency in provoking seismic events and to calculate its correlation with blasting parameters. The investigation was carried out for one mining division in the Polkowice-Sieroszowice mine over the 2015-2017 period. The group blasting parameters, seismic activity and rockburst hazard were depicted and analyzed. The correlation between the amount of induced energy per one $\mathrm{kg}$ of explosives, the number of blasted faces and the provocation effectiveness related to the number and energy of tremors was calculated.

\section{RESEARCH AREA}

Copper ores occurring in south-west Poland are a part of Kupferschiefer of northern central Europe of which the exploitation started in the 12th century in the Mansfeld district of Germany. Three deep mines, i.e., Rudna, Lubin and Polkowice-Sieroszowice (P-S) owned by KGHM Polish Copper JSC have been excavating the copper deposit in Poland for about fifty years. The present Polkowice-Sieroszowice mine operates in Polkowice, Sieroszowice, Radwanice-East (Radwanice-Wschód) and Deep Industrial Głogów (Głogów Głęboki Przemysłowy - GGP) mining areas (MA in short) (Fig. 1). The GGP area is adjacent also to Rudna mine and will be eventually mined by both 
Rudna mine and Polkowice-Sieroszowice mine. The total area of the P-S MA reaches $176 \mathrm{~km}^{2}$ including $75.2 \mathrm{~km}^{2}$ of Polkowice MA, $97 \mathrm{~km}^{2}$ of Sieroszowice MA and $3.4 \mathrm{~km}^{2}$ of Radwanice-East MA. The copper ore deposit is opened by two shafts and several roads and drifts (Kijewski 2006; Piestrzyński 2007).

The copper ore deposit is situated in the Fore-Sudetic Monocline in south-western Poland in Legnica-Głogów Copper District (LGCD). The bedrock of the Fore-Sudetic Monocline is made of Proterozoic metamorphic rocks such as crystalline shales, gneisses, granite-gneisses, phyllites, amphibolites and of Carboniferous sedimentary rocks, which are covered by Permian and Triassic sediments. Rocks with copper mineralization come from the Permian period while the deposit rocks are dated to the borderline of the Rotliegend and Zechstein i.e. between the Lower and Upper Permian. This period was a time of a radical change in the rock sedimentation environment. In the Lower Permian, the area of the deposit was a sandy desert, which was flooded by the highly saline waters of a shallow sea. Consequently, copper-bearing rocks are represented by sandstones which were formed in a desert environment, as well as dolomites and shales, which are of marine origin (Piestrzyński 2007; Barlett et al. 2013).

The Polkowice-Sieroszowice mine was established in 1996 by merging two mines, i.e., Polkowice and Sieroszowice. In 1963 the Polkowice mining plant was started, while the Sieroszowice one began exploitation in 1980 (Kijewski 2006; Barlett et al. 2013).

The G-23 mining division, which was selected for analyses, belongs to Polkowice MA and is located in the northwest of the region. The analysis of seismic hazard covers 2015-2017 years. The room-and-pillar mining system with roof self-deflection (J-UG-PS, the acronym in Polish) is used to extract ores. This method is designed to mine pseudo-seam deposits with a thickness of 4.5 to 6 meters and inclination up to $8^{\circ}$. Furthermore, roof bolting support system can be applied successfully. The length of the exploitation front is to be at least 200 meters. If the thickness of a deposit is less than 4.5 meters mine workings should be constructed close to a roof. Ahead of the front, cutting is conducted in the way, which can create yield zones in the pillars and solid edge. Consequently, the pillars work in the post-destruction state; they are called technological ones. The deposit is cut into pillars and rooms and technological pillars of 5-9 meters by 6-16 meters dimension are left to protect the roof of mined-out area. The mine workings made by the cutting should be up to 6 meters wide and up to 4.5 meters high depending on the deposit thickness. The exploitation depth reaches 700 meters. The highest level of rockburst hazard has been established for the G-23 division (Kijewski 2006; Butra 2010; Piestrzyński 2007).

\section{RESULTS AND DISCUSSION}

Investigation of the provocation efficiency of group winning blasting was carried out for the G-23 division over the 2015-2017 period. First of all seismic activity 
was calculated to find periods of low and high seismicity. The efficiency of the use of group blasting to reduce the seismic and rockburst hazards through the energy released from the rock mass was analyzed and assessed. The number of blasted faces and the ratio of induced seismic energy to the number of explosives were taken into account. The correlation between the aforementioned blasting parameters, induced energy and the efficiency of the provocation of tremors and rock bursts was investigated.

\subsection{SEISMIC ACTIVITY}

Seismic activity in the G-23 division in years 2015-2017 was high. It was depicted by the number and energy of tremors and rock bursts. A tremor has been defined as a seismic phenomenon with the energy of $E \geq 1 \cdot 10^{3} \mathrm{~J}$ while a high-energy tremor as an event with $E \geq 1 \cdot 10^{5} \mathrm{~J}$ energy. The seismic activity is illustrated in Table 1 . In years 2015-2017, in the G-23 division, 2011 tremors with the total energy of $4.99 \cdot 10^{8} \mathrm{~J}$ took place including 305 high-energy ones with the total energy of $4.71 \cdot 10^{8} \mathrm{~J}$ $\left(1.54 \cdot 10^{6} \mathrm{~J} / 1\right.$ tremor $)$.

In 2015 there were 855 tremors with the total energy of $1.93 \cdot 10^{8} \mathrm{~J}$. In 2016 the number of tremors dropped to 656 and their total energy increased to $2.21 \cdot 10^{8} \mathrm{~J}$ compared to the year 2015. In 2017 the number of tremors decreased to 500 and their total energy also decreased to $8.5 \cdot 10^{7} \mathrm{~J}$ compared to the 2016 year. In 2015 the energy per one tremor was $2.26 \cdot 10^{5} \mathrm{~J}$, in 2016 it increased to $3.37 \cdot 10^{5} \mathrm{~J}$ and in 2017 it decreased to $1.7 \cdot 10^{5} \mathrm{~J}$. In years $2015-2017$ the average energy per one tremor was $2.48 \cdot 10^{5} \mathrm{~J}$. It can be noticed that the total seismic energy was substantial in 2015 and 2016, then it decreased by $50 \%$ in 2017 . The number of tremors decreased over the analyzed period by $42 \%$. The majority (137) of high-energy tremors occurred in 2015, in 2016 fewer tremors were recorded (95) and in 2017 there was the smallest number (73) of highenergy events. In 2015, the total energy of high-energy tremors reached $1.81 \cdot 10^{8} \mathrm{~J}$ and in 2016 it reached $3.12 \cdot 10^{8} \mathrm{~J}$ and then decreased to $7.76 \cdot 10^{7} \mathrm{~J}$. The biggest energy per one high-energy tremor $\left(2.23 \cdot 10^{6} \mathrm{~J}\right)$ was in 2016 . It can be stated that the energy of tremors decreased over the 2015-2017 period, which indicates that the seismic risk was reduced. At the beginning of 2017, the development of the mining front in the division was ceased gradually.

In the G-23 division over the 2015-2017 years, there were 8 rock bursts with a total energy of $3.17 \cdot 10^{7} \mathrm{~J}$. In 2015,4 rock bursts $\left(1.88 \cdot 10^{7} \mathrm{~J}\right)$ occurred, while in 2016 , there were 3 rock bursts $\left(9.8 \cdot 10^{6} \mathrm{~J}\right)$. In 2017 , the number and energy of rock bursts decreased significantly compared to two previous years; there was one rockburst with the energy of $3.1 \cdot 10^{6} \mathrm{~J}$. It can be noticed that the number and energy of rock bursts decreased over the 2015-2017 period. Such a decrease of seismic hazard may indicate that preventive measures were efficient in constraining the seismic hazard. 
Table 1. Seismic activity in G-23 mining division related to energy classes in years 2015-2017

\begin{tabular}{|c|c|c|c|c|c|c|c|c|c|}
\hline \multirow{2}{*}{ Year } & \multicolumn{5}{|c|}{$\begin{array}{c}\text { Energy cass } \\
{[\mathrm{J}]}\end{array}$} & $\begin{array}{c}\text { Number } \\
\text { of tremors }\end{array}$ & $\begin{array}{c}\text { Energy } \\
{[\mathrm{J}]}\end{array}$ & $\begin{array}{c}\text { Energy } \\
\text { per one } \\
\text { tremor } \\
{[\mathrm{J}]}\end{array}$ \\
\cline { 2 - 11 } & $10^{3}$ & $10^{4}$ & $10^{5}$ & $10^{6}$ & $10^{7}$ & $10^{8}$ & & & \\
\hline 2015 & 460 & 258 & 98 & 37 & 2 & 0 & 855 & $1.93 \cdot 10^{8}$ & $2.26 \cdot 10^{5}$ \\
\hline 2016 & 336 & 225 & 71 & 23 & 0 & 1 & 656 & $2.21 \cdot 10^{8}$ & $3.37 \cdot 10^{5}$ \\
\hline 2017 & 258 & 169 & 55 & 17 & 1 & 0 & 500 & $8.50 \cdot 10^{7}$ & $1.70 \cdot 10^{5}$ \\
\hline Total & 1054 & 652 & 224 & 77 & 3 & 1 & 2011 & $4.99 \cdot 10^{8}$ & $2.48 \cdot 10^{5}$ \\
\hline
\end{tabular}

\subsection{GROUP WINNING BLASTING IN ROCK BURST PREVENTION}

The seismic hazard can be controlled to some extent with the use of various preventive measures such as technological, active and organizational-technical activities. Technological methods rely on making the edges of solid and pillars within the cutting area yield, using technologies with a wide mining front as well as adjusting the size of technological pillars to geological and mining conditions. Organizationaltechnical methods include investigation of the geological structure of the rock mass, determination of the order and direction of mining, implementation of proper observation methods, determination of special hazard zones and the time length to wait after blasting.

The active methods embrace group winning blasting of the maximum number of faces and blasting in the floor and the roof. The purpose of active prevention is to relieve stresses in the rock mass by provoking a tremor or a rock burst to occur. Blasting works are carried out in the faces of chambers to extract the ores. To induce/provoke the rock mass relaxation, blasting is also used in the walls of pillars and the floor of the workings. Winning blasting is applied to exploitation fronts and brings the expected results. Moreover, such activities may relieve in-situ stress and hence can induce high-energy dynamic seismic events. Simultaneous blasting a dozen or more faces can be efficient since the blasted holes are located within the operating zone. Blasting is performed both in winning and long stress-relieving holes, which enables one to use more explosives and thereof provoke larger energy release. Inducing the rock mass relaxation with group blasting works consists in the simultaneous deprivation of supporting of the roof layers in a significantly long part of the front and a transformation of the stress from triaxial to uniaxial in the deposit part. If a roof loses support in a large part of the front, an additional load to the next heavily loaded deposit part is simultaneously applied. This can induce rock bursts, but only by concurrent blasting at least several dozen of adjacent faces in subsequent parts of the exploitation front. The effectiveness of provoking a rock mass to vibrate depends on the state of stresses and the length of the front. Preventive meth- 
ods based on provoking seismic events by blasting allows one to control the time of occurrence of seismic phenomena. Based on the previous experience in the KGHM mines, it was found that group winning blasting induces tremors efficiently. After provocative blasting, waiting time is implemented (Konopko 2009; Butra 2010; Piestrzyński 2007; Kłeczek 2004).

In the G-23 division, clear rules for blasting were adopted. They included maximizing the number of faces and maintaining a level line of cutting. Winning and stress relieving holes were used in the main faces. When this was impossible, an increased charge of explosives was used in all holes. When necessary, the same stress relief blasting was performed in the floor with blast holes along technological pillars or in the excavation axis (Butra 2010; Piestrzyński 2007; Kłeczek 2004).

The winning group blasting works in the G-23 division were characterized by the number of faces blasted concurrently and the number of explosives used. These parameters were analyzed over the 2015-2017 period. Table 2 includes the number of faces blasted in particular months in each year. In 2015, 4,491 faces were blasted, and in $2016,3,737$ ones. The number of faces in 2017 dropped to 2,210. The monthly number of faces in 2015 varied from 425 to 300 (374 on average); in 2016 this number varied from 388 to 250 ( 311 on average) and in 2017 the number of faces varied from 270 to 126 (184 on average) and was relatively stable in each year. It can be seen that the number of faces decreased in subsequent years by $51 \%$, which may indicate gradual ceasing of exploitation, which was partly connected with large areas of gangue (stone) rocks occurring in the deposit.

In $2015508,300 \mathrm{~kg}$ of explosives were blasted, in 2016 and 2017 the amount of them decreased to $477,630 \mathrm{~kg}$ and $393085 \mathrm{~kg}$ respectively. In $2015,113 \mathrm{~kg}$ of explosives were used in one face on average, in 2016 such amount was $128 \mathrm{~kg}$ and in 2017 it was the biggest reaching $178 \mathrm{~kg}$.

Table 2. Number of faces blasted in G-23 division in a given month in years 2015 and 2017

\begin{tabular}{|c|c|c|c|c|c|c|c|c|c|c|c|c|c|c|}
\hline Month & I & II & III & IV & V & VI & VII & VIII & IX & X & XI & XII & $\begin{array}{c}\text { Number } \\
\text { of faces }\end{array}$ & $\begin{array}{c}\text { Faces } \\
\text { Month }\end{array}$ \\
\hline Year & \multicolumn{10}{|c|}{2015} \\
\hline $\begin{array}{c}\text { Number } \\
\text { of Faces }\end{array}$ & 376 & 368 & 396 & 372 & 368 & 408 & 425 & 345 & 390 & 398 & 345 & 300 & 4,491 & 374 \\
\hline Year & \multicolumn{10}{|c|}{2016} \\
\hline $\begin{array}{l}\text { Number } \\
\text { of Faces }\end{array}$ & 339 & 356 & 388 & 359 & 345 & 352 & 310 & 274 & 265 & 261 & 238 & 250 & 3,737 & 311 \\
\hline Year & \multicolumn{10}{|c|}{2017} \\
\hline $\begin{array}{l}\text { Number } \\
\text { of Faces }\end{array}$ & 240 & 240 & 270 & 161 & 168 & 172 & 161 & 168 & 170 & 175 & 159 & 126 & 2,210 & 184 \\
\hline
\end{tabular}




\subsection{EFFICIENCY OF GROUP WINNING BLASTING IN SEISMIC HAZARD MITIGATION}

The efficiency of seismic event provoking with the group winning blasting means the percentage of the number and energy of induced tremors and rock bursts in their total number and energy over a given time. The bigger the percentage is, the more efficient the group blasting is in constraining the seismic hazard. The efficiency for tremor energy is the most decisive factor since the energy released from the rock mass does reduce the hazard. The ratio of provoked/induced energy to the number of explosives was also calculated since it can indicate the degree of blasting efficiency in seismicity reduction. The bigger the induced energy is obtained with one kilogram of explosives, the more efficient blasting is. The efficiency was assessed for the G-23 division over 2015-2017 years. The analysis covered rock bursts and tremors of the energy of $E \geq 10^{3} \mathrm{~J}$.

Throughout the 2015-2017 years, blasting works provoked 4 rock bursts $\left(1.23 \cdot 10^{7} \mathrm{~J}\right)$, which resulted in $50 \%$ of provocation efficiency related to the number of rock bursts and $41 \%$ of that related to energy. In 2015 , one $\left(5.9 \cdot 10^{6} \mathrm{~J}\right)$ rockburst was induced, which indicated $25 \%$ effectiveness for their number and $31 \%$ for energy. In 2016,2 rock bursts were provoked $\left(5.2 \cdot 10^{6} \mathrm{~J}\right)$, which meant the provocation efficiency of $59 \%$ for the number of rock bursts and of $53 \%$ for their energy. In 2017 , there was only one rockburst $\left(3.1 \cdot 10^{6} \mathrm{~J}\right)$ and it was provoked, so the efficiency achieved $100 \%$ for both number and energy. It can be noticed that the provocation of rock bursts by group blasting was efficient, satisfactory and improved successively.

In 2015 , the provocation efficiency related to the number of tremors was $38 \%$ and that related to energy amounted to $68 \%$. In 2016 , the efficiency for the tremor number was $40 \%$ and for the tremor, energy reached $34 \%$. In 2017 , the efficiency of provocation related to the tremor number was $27 \%$ and that related to energy was $28 \%$. From 2015 through 2017 tremors were induced with an average efficiency of $36 \%$ for their number and of $46 \%$ for energy. It can be noticed that the provocation efficiency was satisfactory in 2015 but over the 2016-2017 period it became relatively poor (Table 3). As mentioned above, the provocation efficiency connected with energy is the most crucial to constrain the seismic hazard. Only in 2015, such efficiency was very high and the group winning blasting was satisfactory. However, in 2016 and 2017, the efficiency for energy decreased to $34 \%$ and $28 \%$, respectively, due to excavation ceasing; more liquidation works were conducted.

The ratio of induced energy to amount of explosives was the highest in 2015 achieving $255.8 \mathrm{~J} / \mathrm{kg}$, next in 2016 it dropped to $156.6 \mathrm{~J} / \mathrm{kg}$ and in 2017 it decreased significantly to $61.1 \mathrm{~J} / \mathrm{kg}$. It can be seen that the more energy was induced with $1 \mathrm{~kg}$ of explosives, the higher the efficiency of tremor provocation was achieved. 
Table 3. The efficiency of blasting related to the number and energy of tremors and number of explosives in G-23 division

\begin{tabular}{|c|c|c|c|}
\hline Year & $\begin{array}{c}\text { Efficiency related to } \\
\text { number of tremors } \\
{[\%]}\end{array}$ & $\begin{array}{c}\text { Efficiency related to } \\
\text { energy of tremors } \\
{[\%]}\end{array}$ & $\begin{array}{c}\text { Energy of tremor } \\
\text { per 1 kg of explosives } \\
{[\mathrm{J} / \mathrm{kg}]}\end{array}$ \\
\hline 2015 & 38 & 68 & 255.8 \\
\hline 2016 & 40 & 34 & 156.6 \\
\hline 2017 & 27 & 28 & 61.1 \\
\hline $2015-2017$ & 36 & 46 & 165.9 \\
\hline
\end{tabular}

\subsection{INFLUENCE OF GROUP WINNING BLASTING PARAMETERS ON SEISMIC HAZARD}

The relationship between the efficiency of the group blasting in the provocation of tremors, the number of blasted faces and the ratio of the induced energy to the number of explosives were determined. Monthly parameters were taken into account over the 2015-2017 period (Table 4). Pearson linear correlation coefficients were calculated. The analysis was carried out for tremors of $E \geq 1 \cdot 10^{3} \mathrm{~J}$ energy in the G-23 division.

In 2015 , monthly provocation efficiency related to tremor number varied from $28 \%$ to $54 \%$ and that related to energy changed from $32 \%$ to $94 \%$, whereas the induced energy per one $\mathrm{kg}$ of explosives changed from $64 \mathrm{~J} / \mathrm{kg}$ to $494 \mathrm{~J} / \mathrm{kg}$. In 2016 , monthly provocation efficiency related to tremor number varied from $20 \%$ to $51 \%$ and that related to energy changed from $0.6 \%$ to $94 \%$. The induced energy per one $\mathrm{kg}$ of explosives changed from $16 \mathrm{~J} / \mathrm{kg}$ to $642 \mathrm{~J} / \mathrm{kg}$. In 2017 , monthly provocation efficiency related to tremor number varied from $5 \%$ to $62 \%$ and that related to energy changed from $1 \%$ to $90 \%$. The induced energy per one $\mathrm{kg}$ of explosives changed from $0.9 \mathrm{~J} / \mathrm{kg}$ to $171 \mathrm{~J} / \mathrm{kg}$.

A strong linear relationship with the correlation coefficient of 0.7 was obtained between the provocation efficiency for the energy of tremors and the amount of induced energy per one $\mathrm{kg}$ of explosives, whereas the linear correlation coefficient between the efficiency for the number of tremors and the amount of energy induced with one $\mathrm{kg}$ of explosives was weaker and amounted to 0.35 .

The moderate linear relationship was found between the provocation efficiency and the number of blasted faces. The linear correlation coefficient between the number of faces and the efficiency was 0.46 (for tremors' number) and 0.51 (for tremors' energy).

The very poor linear relationship was found between the effectiveness of tremor provocation and the number of explosives. The linear correlation coefficient between the number of explosives and the efficiency was 0.06 (for tremors' number) and 0.28 (for tremors' energy). The linear correlation coefficient of 0.52 was obtained between the efficiency related to the number of tremors and efficiency related to the energy of tremors, which indicated a medium linear relationship. 
It can be said that the more energy was released per one $\mathrm{kg}$ of explosives, the larger provocation efficiency for the energy of tremors was achieved. Similarly, the more faces were blasted, the bigger efficiency for energy provocation was achieved.

Table 4. Monthly efficiency of blasting related to number and energy of tremors and amount of explosives in G-23 division in years 2015-2017

\begin{tabular}{|c|c|c|c|c|c|c|c|c|c|c|c|c|}
\hline Month & I & II & III & IV & $\mathrm{V}$ & VI & VII & VIII & IX & $\mathrm{X}$ & $\mathrm{XI}$ & XII \\
\hline Year & \multicolumn{12}{|c|}{2015} \\
\hline $\begin{array}{l}\text { Efficiency } \\
\text { tremor number [\%] }\end{array}$ & 28 & 35 & 31 & 51 & 54 & 38 & 35 & 39 & 32 & 31 & 44 & 33 \\
\hline $\begin{array}{l}\text { Efficiency } \\
\text { tremor energy [\%] }\end{array}$ & 66 & 50 & 91 & 89 & 94 & 51 & 67 & 32 & 49 & 85 & 51 & 43 \\
\hline Energy/explosives [J/kg] & 124 & 168 & 282 & 412 & 299 & 183 & 378 & 64 & 115 & 537 & 494 & 153 \\
\hline Year & \multicolumn{12}{|c|}{2016} \\
\hline $\begin{array}{l}\text { Efficiency } \\
\text { tremor number [\%] }\end{array}$ & 36 & 33 & 49 & 25 & 35 & 51 & 20 & 44 & 48 & 49 & 50 & 41 \\
\hline $\begin{array}{l}\text { Efficiency } \\
\text { tremor energy [\%] }\end{array}$ & 94 & 68 & 88 & 82 & 13 & 45 & 0.6 & 27 & 34 & 78 & 88 & 47 \\
\hline Energy/explosives [J/kg] & 642 & 208 & 341 & 139 & 30 & 52 & 16 & 49 & 39 & 69 & 181 & 98 \\
\hline Year & \multicolumn{12}{|c|}{2017} \\
\hline $\begin{array}{l}\text { Efficiency } \\
\text { tremor number [\%] }\end{array}$ & 45 & 62 & 28 & 28 & 10 & 5 & 15 & 9 & 20 & 23 & 25 & 20 \\
\hline $\begin{array}{l}\text { Efficiency } \\
\text { tremor energy [\%] }\end{array}$ & 66 & 60 & 18 & 7 & 1 & 3 & 28 & 20 & 90 & 3 & 52 & 23 \\
\hline Energy/explosives [J/kg] & 63 & 161 & 115 & 49 & 2 & 0.9 & 9 & 17 & 171 & 4 & 100 & 41 \\
\hline
\end{tabular}

\section{CONCLUSIONS}

1. Over the 2015-2017 period, in the G-23 mining division, the seismic activity stayed increased, which necessitated the implementation of the group winning blasting to diminish rockburst hazard. In successive years the entire number and amount of energy of tremors and rock bursts decreased significantly, which may be related with a satisfactory amount of energy released by blasting and to some extent with ceasing the exploitation.

2. The achieved outcomes indicated that the group blasting provocation efficiency decreased in successive years but remained at the level satisfactory enough to reduce the rockburst hazard.

3. The group blasting efficiency in energy provocation assessed by the amount of energy released through one kilogram of explosives correlated well with that assessed by the percentage of energy induced with blasting. 
4. In 2015-2017 in the G-23 division the efficiency of inducing the tremors for both the number and energy did not depend on the number of explosives but they were directly proportional to the number of blasted faces. The energy and number of induced tremors increased moderately with the increasing number of faces. Similarly, the provocation efficiency for energy increased moderately with that for the number of tremors. Moreover, the provocation efficiency for energy was strongly proportional to the amount of energy induced by one kilogram of explosives. To verify these results subsequent analyses should be performed in various mining circumstances and over a long time.

5. The obtained outcomes show that the assessment of the provocation effectiveness of group blasting is inevitable to monitor the seismic hazard to some extent.

\section{REFERENCES}

BARTLETT S., BURGESS H., DAMJANOVIĆ B., GOWANS R., LATTANZI C., 2013,. Raport techniczny dotyczacy produkcji miedzi i srebra przez KGHM Polska Miedź S.A. w Legnicko-Głogowskim Okregu Miedziowym w poludniowo-zachodniej Polsce (Technical report on the production of copper and silver by KGHM Polish Copper JSC in the Legnica-Glogów Copper District in south-western Poland), KGHM Polska Miedź S.A., Lubin (in Polish).

BUTRA J., 2010, Eksploatacja złoża rud miedzi $w$ warunkach zagrożenia tapaniami i zawałami (Exploitation of the copper ore deposit under conditions of rock bursts and roof falls), KGHM Cuprum Sp. z o.o., Wrocław (in Polish).

KIJEWSKI P. (Ed.), 2006, Monografia, Zakłady Górnicze Polkowice-Sieroszowice (Monography Polkowice-Sieroszowice Mining Plant), KGHM Cuprum Sp. z o.o., Wrocław (in Polish).

KŁECZEK Z., 2004, Grupowe strzelanie przodków jako element profilaktyki tapaniowej w kopalniach rud miedzi LGOM (Group blasting as a part of rock burst prevention in LGOM copper mines), Górnictwo i Geoinżynieria, 28, 153-159 (in Polish).

KONOPKO W., 2009, Wieloźródtowość wstrzqsów górotworu (Multi-origin of induced tremors), Przegląd Górniczy, 65, 72-75 (in Polish).

PIESTRZYŃSKI A. (Ed.), 2007, Monografia KGHM Polska Miedź S.A. (Monography of KGHM Polish Copper JSC), KGHM Cuprum Sp. z o.o., Wrocław (in Polish). 